\title{
BARGAINING POWER AND MARKET DEFINITION: A REFLECTION ON TWO MERGERS
}

\author{
Simon Roberts* \\ UJ Centre for Competition Economics \\ Competition Commission SA \\ Simonr@compcom.co.za \\ Catherine Corbett ${ }^{\#}$ \\ catherineanncorbett@gmail.com \\ Reena das Nair+ \\ UJ Centre for Competition Economics \\ Competition Commission SA \\ reenad@compcom.co.za
}

April 2011

\begin{abstract}
When assessing whether a merger is likely to substantially prevent or lessen competition, the Competition Act, No. 89 of 1998, as amended, specifies that the Commission should assess the strength of competition by taking into account the degree of countervailing power in a market. We highlight the importance of understanding this in terms of the factors underlying bargaining power, such as the alternative sources of supply available to buyers, the alternative sources of demand to sellers, cost structures, and information asymmetries. To do this we critically compare the approach adopted by the Competition Tribunal in evaluating two mergers: Sasol/Engen and Chlor-Alkali Holdings/Botash. We find that in both cases an analysis of bargaining power should play an important part in the assessment of the effects on competition, including the identification of competitive constraints that fall within market definition.
\end{abstract}

\section{Keywords}

Countervailing power, bargaining power, buyer power, outside options, market definition, market power, merger analysis, unilateral effects

\footnotetext{
* Dr Simon Roberts is an Associate of UJ Centre for Competition Economics and the Chief Economist at the Competition Commission, South Africa.

\# Ms Catherine Corbett was formerly a Junior Economist at the Competition Commission, South Africa.

+ Ms Reena das Nair is an Associate of UJ Centre for Competition Economics and a Principal Economist at the Competition Commission, South Africa.
}

The views expressed in this paper are those of the authors and do not necessarily represent the views of $U J$ Centre and the Competition Commission. 


\section{INTRODUCTION}

Market definition is one of the key steps in merger evaluation by competition authorities; however, both its role and the appropriate methodologies continue to be extensively debated in the academic literature as well as by competition practitioners (see, for example, Baker \& Bresnahan, 2006; Kaplow, 2010; Carlton, 2007). We focus on one particular question, namely the way in which bargaining power is taken into account, and we assess how the South African Competition Tribunal addressed this in two important mergers.

Economists traditionally talk of a market as an area in which 'prices of the same goods tend to equality with due allowance for transportation costs' (Marshall, 1920, as cited in Carlton \& Perloff, 2000:612). This is what Geroski (1998) terms a 'trading market', and Scheffman and Spiller (1987:125) an 'economic market', being 'an area within which partial equilibrium analysis is valid'. This assumes relatively homogeneous products and many buyers.

Market definition appears similar in antitrust in being about specifying 'the competing products and geographic area in which competition occurs that determines the price for a given product' (Carlton \& Perloff, 2000:612). This primarily involves identifying demand-side substitutes to which consumers can turn in response to a price increase, but also requires examination of supply-side substitution and various dimensions of product differentiation and positioning.

Viewed in terms of being about identifying sources of competitive constraints, antitrust markets can also be identified in terms of a set of products and a geographic area which would be worth monopolising, as captured in the hypothetical monopolist test (Geroski, 1998; Church \& Ware, 2000:602). If there are close substitutes for consumers to avoid the effect of a price increase, these substitutes would have to be included in the market being monopolised. A hypothesised single supplier of the products would then be able to exert substantial market power in that it would be profitable for it to implement a small but significant non-transitory increase in price (or SSNIP). Market definition is thus about a search for market power, and the competitive constraints on firms who might exert it (Motta, 2004; Carlton, 2007). In the context of merger analysis, it is specifically about understanding the changes in market power that may result from a transaction.

While there is widespread agreement that market definition is but an intermediate step in the analysis of the effect of a merger, the question as to how to factor in constraints on market power in the context of different models of price formation, especially with few buyers and sellers, produces a wide range of answers. At one extreme are those who dismiss the market definition exercise as pointless, as the main objective of assessing market power can and should be done directly (for example, Kaplow, 2010). At the other are those who argue strongly for market definition as a distinct and separate process of demand-side substitutability, unpolluted by a wider consideration of sources of competitive discipline over pricing (Baker, 2007).

We seek to understand and illustrate one area in particular and, rather than take sides on where the boundary of the market definition exercise ends and the analysis of competitive effects begins, emphasise that the point is that the overall analysis is coherent and integrated, bringing together relevant theories and the necessary data. It is in these terms that we critically assess the way in which the Competition Tribunal addressed the questions of market definition, market power and price determination in two mergers which turned on relative bargaining power with concentrated suppliers and buyers. 
In such situations the assumption that the market clears through supply decisions (whether of many, or a few oligopolists) against a demand curve representing the preferences of many independent buyers is not justified.

Similarly, the textbook theory of monopsony power (Carlton \& Perloff, 2000:105), where there is a single buyer and many suppliers, is also not appropriate. In this model the buyer can exploit an upward sloping supply curve to obtain lower prices given a perceived marginal expenditure curve to the monopsonist above the supply curve, yielding socially inefficient under-production and deadweight loss (Chen, 2007). Such considerations have been important in examinations of the power of major retailers in Europe (see Clarke et al., 2002).

Buyer power has also been addressed in terms of countervailing power, where concentrated buyers are able to counter the market power of concentrated suppliers. Typically in mergers it is used as a consideration that could mitigate an otherwise anti-competitive merger (Motta, 2004:237; Inderst \& Shaffer, 2008; Inderst \& Valletti, 2007). The degree of countervailing power in the market is one of the factors identified in the South African Competition Act for the consideration of mergers (under sl2A(2)(d)).

We discuss two mergers where the market outcomes were evidently the result of bargaining. We examine how the competitive constraints were taken into account by the Competition Tribunal, against the factors identified by theories of bargaining games, and the inter-relationship with market definition. The mergers were judged to have anti-competitive consequences because they lessened the bargaining power on the part of buyers, rather than their effects being mitigated by countervailing power.

The two mergers reviewed here included the merging party acquiring a supplier of the same product located some distance away. In Sasol/Engen merger, the Tribunal viewed the Engen refinery as not being in the same market as the Sasol refineries due to transport constraints and hence viewed the merger as primarily vertical in nature. The effect of the merger on the bargaining power was still critical to the Tribunal prohibiting the merger but was framed largely in terms of the likelihood of foreclosure. In the Botash/ChlorAlkali Holdings (CAH) merger the Tribunal included the supplier being purchased in the market, and considered the countervailing power argument as a key aspect of the analysis. This meant that the merger took on a distinctly horizontal aspect and conditions were attached relating to post-merger price and supply.

The structure of the paper is as follows.

- Section 2 briefly reviews market definition in mergers and the treatment of buyer power.

- Sections 3 and 4 provide a critical analysis of the Tribunal's treatment of the Sasol/Engen and Botash/CAH mergers.

- Section 5 concludes.

\section{MARKET DEFINITION AND BARGAINING POWER IN MERGER ANALYSIS}

\subsection{Market definition}

Market definition in competition analysis is a purposive process. In mergers it is done in order to identify the scope of competition and existing market power of the merging parties in order to assess whether the merger is likely to have the effect of substantially lessening or preventing 
competition. Typically in mergers this involves starting narrowly with the products made by the merging parties and assessing other products which exercise a competitive constraint on them (see, for example, Motta, 2004; Bishop \& Walker, 2010).

This exercise needs to be undertaken afresh for each case, as the analysis can differ. For example, some customers of storage drums may have to utilise steel drums because of the hazardous nature of the chemicals they wish to pack, while others can use plastic and steel. Producers of plastic drums will be disciplined by those producing steel drums, but the opposite is not necessarily the case. Just such questions arose in one of the first mergers assessed by the South African Competition Tribunal (Case 06/LM/0ct99).

It is necessary to understand how products are supplied, consumed, and marketed, in order to be able to select the appropriate tools from the economic theory toolbox, rather than for the exercise to be one of simplistically drawing boundaries. In this sense market definition is a framework for collecting and organising information involving the nature of competitive behaviour and firms' decision-making. This is readily evident in the treatment of time and convenience in consumption decisions in markets as diverse as local air travel, where separate markets could be defined for time-sensitive and non-time-sensitive travel (Competition Tribunal Case 80/CR/Sep06), and impulse ice-cream (as in the UK Van Den Bergh case, 0 'Donoghue \& Padilla, 2006). In the JD-Ellerines merger the South African Competition Tribunal identified the importance of offering sales on credit and the competencies involved in defining the market in these terms rather than simply for the sale of furniture (Competition Tribunal Case 78/LM/Jul00).

Recognition of the many dimensions along which products can be, and are, differentiated led to the US antitrust authorities issuing revised Horizontal Merger Guidelines in 2010 to better describe the range of analysis they were actually undertaking in such cases (U.S. Department of Justice and the Federal Trade Commission, 2010). The Guidelines included an 'Upward Pricing Pressure' test that seeks to go directly to the possible price-raising effects of a merger where some of the sales lost by a firm that raises price are diverted to the firm now being acquired (see contributions in Hawk, 2011).

The burgeoning literature on two-sided markets recognises the complexities of defining markets and understanding competition where a platform of consumers is developed on one side for the purposes of selling access to the other (Evans \& Schmalensee, 2005). For example, commercial radio stations build up a listener base for the purpose of selling access to them to advertisers. Credit card companies get subscribers in order to sell the service to merchants. The market can be defined in terms of customers on both sides, but it is critical to understand the interaction between the two sides of the market.

Rather than being fixated on what is covered under the heading of market definition, the priority is to ensure that the economic analysis of the merger is well founded in economic theory, and assesses the appropriate information (Hay \& Vickers, 1987). This emphasis on the exercise as an appropriate frame of reference for the analysis of the competitive effects is reflected in the practice of competition authorities (ICN, 2006). It is in this light that we now turn to the treatment of bargaining power in merger analysis.

\subsection{Bargaining power, and the assessment of market power}

A bargaining problem in its simplest form can be considered through the following example (see Hargreaves, Heap \& Varoufakis, 2004; Osborne \& Rubinstein, 1990). Two agents, A and B, have 
the opportunity to split R100 between them if they can agree on a distribution in Rands for each. We empower $A$ to make $B$ an offer that $B$ may accept or reject. If $B$ accepts then the division is determined by A's offer. If $B$ rejects, we assume R80 is lost and then $B$ can make an offer on the split for the remaining $\mathrm{R} 20$. If $A$ rejects this offer they both end up with nothing. We assume away risk aversion and envy, assuming that agents' utilities are directly proportional to their own pay-offs, and that there is a common knowledge of rationality of each agent.

The solution is the offer that A makes that B must accept. The most B can get if she rejects is $R 19$, as this means offering $A$ in the second round the smallest pay-off possible (of Rl) and keeping R19 of the R20 for herself. Therefore, by backwards induction, A offers a split of R80 for himself and R20 for B.

Consider now if B threatens that she will reject any offer by A that is less than R50. This is not credible, and $A$ will know this given the information he has and the common knowledge of rationality.

This simple example points to the importance of credibility and commitment in bargaining, the information that each side has, and the alternative options.

This can be thought of as the agreement on the price of an intermediate good between an upstream producer and a downstream firm, with the downstream firm further processing before selling to end consumers. Imagine that the alternative is that end consumers turn to an imported final product. Without an agreement between the two firms the end product will not be supplied and the surplus available from it will not be realised.

This is very similar to the framework of the 'bargaining interface' in Inderst and Shaffer (2008). This describes a single buyer and single seller in negotiation over a single unit, which costs the seller $\$ 5$ to produce and which the buyer can re-sell to some final consumer at a price of $\$ 10$. Hence jointly the firms can realise a profit of $\$ 5$. The upstream firm has an alternative of selling the product itself to a final consumer at $\$ 7$, yielding a net profit of $\$ 2$ after its own $\$ 5$ production cost. The downstream firm can purchase an inferior good on the world market for $\$ 4$ which it can only re-sell for $\$ 5$, yielding it a net profit of $\$ 1$ from its alternative (or 'outside option'). Collectively they can therefore increase their return by reaching an agreement. What is the price paid by the buyer? It must be less than $\$ 9$, as it can realise a $\$ 1$ surplus from its alternative. It must be greater than $\$ 7$, as the seller can realise a $\$ 2$ surplus from its alternative.

- The first question is what price will be agreed, between $\$ 7$ and $\$ 9$ ? This will depend on the relative bargaining power of the two parties.

- A second question is what difference this will hold for consumers. This will depend on how the downstream firm's input cost determines its pricing, and hence on the market structure in the downstream market.

Nash proposed that any solution to such a bargaining problem should satisfy four axioms: independence of utility calibrations; symmetry; Pareto optimality; and, independence of irrelevant alternatives. On the basis of these he found that there is a unique solution, given the utility functions of the parties (Osborne \& Rubinstein, 1990). The utility functions of the two players differ according to their risk aversion (and thus the value they place on the possibility of a deal not being reached). The player that is less risk averse thus has more bargaining power (Hargreaves Heap \& Varoufakis, 2004).

A strategic approach where time elapses between alternating offers (time that players value) yields a similar outcome in the form of a Nash equilibrium to what is an extensive game, similar 
to Nash's solution to the bargaining problem, but with time preferences being the driving force of the model (Osborne \& Rubinstein, 1990). The player with a higher discount rate (the more impatient) wants an agreement to be reached more quickly. The effect of players having outside options and the ability to terminate the negotiations can also be considered.

\subsection{Outside options}

Outside options in the simple game (where there is complete information) simply set the parameters within which the bargaining takes place. Large buyers that have a relatively better ability to turn to alternatives than many small buyers do, such as importing or sponsoring an entrant, are commonly understood to have potential countervailing power (Motta, 2004:237; Röller, 2004). Competition authorities thus recognise that countervailing buyer power may mitigate an otherwise anti-competitive merger. However, it depends on the credibility of threatening to resort to an alternative or to otherwise withhold purchases, to which we return below.

To the extent that the alternatives to buyers are inferior (over product or geographic space, and/or time) they would not be included in a standard market definition. These outside options or 'by-pass' opportunities are part of established mechanisms to discipline a monopolist's market power, which are taken into account in models of foreclosure (Rey \& Tirole, 2006:13; Gual et al., 2005:26).

Similarly, the cost that can be imposed on a seller depends on that seller's alternatives, including the profit forgone in reducing output. Where the seller faces several large buyers, rather than just one, the ability of any individual buyer to impose a cost on the seller is much weaker, absent buyer coordination.

\subsection{Imperfect information and credible threats}

In assessments of bargaining power the outcomes are contingent on the credibility of the buyer's threat to turn to what is, for it, a less desirable source of supply, the cost it imposes on the monopolist, and the credibility of the monopolist in threatening to bear this cost which depend on alternatives available to it. This requires examining the nature of information given that the assumption of perfect information is difficult to sustain in assessments of bargaining in realworld situations, such as competition cases. In this regard, parties typically have better information about their own costs and alternatives than those of others, with some parties relatively better informed.

We consider the implications of imperfect information on assessment of the risk preferences of firms, time preference, and on their outside options, which are relevant for the mergers we discuss in the following sections. These go to questions of reputation and the credibility of threats.

Consider a case in which one player may be of two types (risk averse or risk lover), and the other player can only use information about past decisions to assess the probability as to which type the player is. This means that rational players know that their choices convey information and will make their choices with this in mind. In dynamic games of incomplete information players can make apparently sub-optimal choices as investments in 'misinformation' (Church \& Ware, 2000:672). Players can thus establish a reputation. A firm that operates in many markets pays a cost for establishing a reputation, but earns the return from it over all the other markets in 
which it operates, providing the buyers in these markets are aware of the decisions it took when making the investment in the reputation (see also Hargreaves Heap \& Varoufakis, 2004). Reputation effects are also associated with players' time preferences. A firm that develops a reputation for patience places itself in a stronger bargaining position.

These are familiar from literature on predation and entry deterrence where, under imperfect information, actions are taken that involve a sacrifice of current profits today that is outweighed by future profits (see Motta, 2004; Church \& Ware, 2000). Strategic investments can be made by an incumbent to convey a message about efficiency (Fudenburg \& Tirole, 1984). Similar uncertainty about the pay-offs of the dominant firm can support decisions in predation games to appear tough rather than weak (as in the Kreps and Wilson model, see Ordover \& Saloner, 1989). The ability of a monopolist to exercise its market power, and the question of credible commitment, was also highlighted by the Coase conjecture and is addressed in the literature on abuse of dominance (Church \& Ware, 2000; Rey \& Tirole, 2006). As Rey and Tirole (2006:14) note, vertical integration is an important means for the monopolist to avoid being subject to the hold-up of demand for its upstream product by buyers, as it can sell through its own downstream channel (including into different, segmented, markets).

\section{SASOL-ENGEN}

The proposed transaction between Sasol Oil and Engen to form a joint venture, Uhambo Oil Ltd, was prohibited by the Competition Tribunal (Competition Tribunal case 101LMDec04). Sasol is predominantly active in the refining and wholesale supply of fuel products at the upstream level, and Engen is active in the upstream refining and wholesale supply, as well as the retail marketing and distribution of these products at the downstream level. Unless otherwise indicated, the information in this section is drawn from the Tribunal's decision.

This transaction was assessed by the Competition Tribunal as a vertical merger of the main inland refiner (Sasol) with the largest marketer and retailer of fuel products in South Africa, including in the inland region (Engen). The interactions and negotiations between the Sasol and the Other Oil Companies (00Cs) were explored extensively in the hearings; however, they were addressed mainly in the context of Sasol's ability to foreclose and as background to Sasol's interest in the merger.

As we discuss, a more structured approach to the bargaining nature of price determination between Sasol as supplier and the 00 Cs as customers in the inland region would have yielded a better integrated analysis of the nature of competitive constraints and the impact of the merger than that from a separation of market definition from such considerations.

\subsection{Industry structure, products and history of regulation}

The major oil companies, Shell, BP, Total, Engen, Caltex and Sasol, are bulk suppliers of fuel in the upstream market where they have refining capacity and, through their marketing arms, are customers of fuel in other parts of the country where they do not have refining capacity but have developed retail networks (see FIGURE 1, for the inland region).

The refining and marketing capacities of the South African oil companies are not well balanced geographically. Shell, BP and Engen have refining capacity on the KwaZulu-Natal coast and Caltex has a refinery based in Cape Town. Sasol has the synfuels (coal to fuel) production 
facility inland at Secunda and is the majority owner, with Total having the minority stake, of the crude oil-based Natref refinery at Sasolburg.

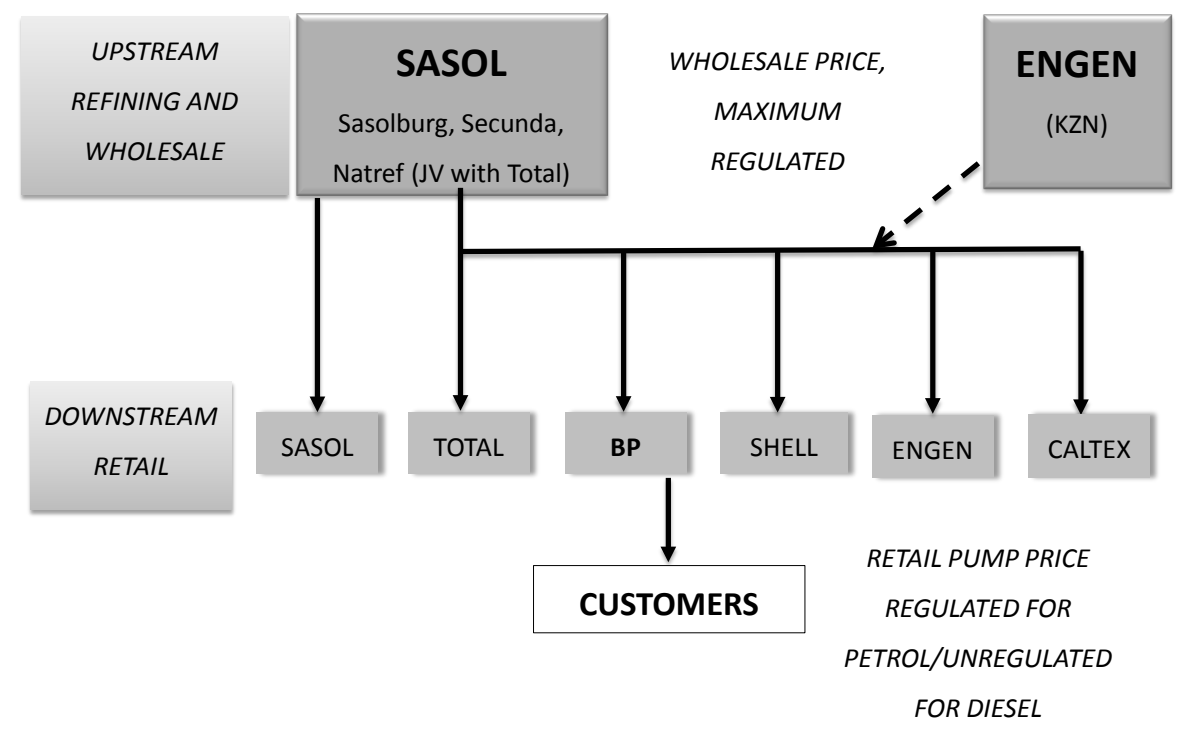

FIGURE 1: Value chain in the inland region

Source: Authors'own deduction

Sasol is dominant in the inland area, with $82 \%$ of refining capacity, while the 00 Cs have to buy from it in order to supply to customers in the inland market, or have to transport product from the coast (from the Engen and Sapref refineries in KZN). The largest market for fuel is in the inland region with over $60 \%$ of national demand.

Post-merger, Uhambo would comprise the white fuels (petrol, diesel, paraffin and kerosene) produced by Sasol Oil at Secunda, Sasol's $63.64 \%$ share of the Natref refinery as well as Engen's Refinery in Durban upstream. Downstream Uhambo's retail network would comprise the marketing network and service stations controlled by Engen and Sasol's small network.

White fuels are predominantly petrol and diesel. The retail petrol price is regulated at the pump based on import parity pricing (IPP) principles. This IPP calculation is the 'Basic Fuel Price' $(B F P)$, to which government taxes, transport costs and a wholesale margin are added on to get to a wholesale price. The maximum wholesale price is regulated. To this price, a dealer margin and pump rounding factors are added to get to a retail price at the pump for petrol (fixed by regulation). Diesel is not regulated, but margins made on diesel sales are taken into account when determining the regulated petrol price.

A brief history is useful in understanding the motivation behind the proposed JV in relation to threats faced by Sasol from government's intended deregulation of the retail markets and potential increases in the inland-coastal pipeline capacity. These threats would increase the 
attractiveness of the 00Cs' outside options to purchasing their fuel from Sasol inland, reducing Sasol's bargaining power (clearly admitted by Mr Oberholster of Sasol, Tribunal decision, p. 51). The result of this would be an erosion of Sasol's inland pricing of fuel from inland import parity levels.

The configuration of fuel production and supply are intricately linked with Sasol's historical role as a state-owned company and producer of liquid fuels from coal. Substantial investment by the state for strategic reasons to reduce dependence on imported crude oil created a low-cost liquid fuels producer inland. Sasol was privatised at the end of the 1980s, but the regulatory dispensation continued to protect its position. The Main Supply Agreement (MSA) required the $00 C$ s to purchase Sasol's product in the 'Sasol Supply Area', according to their market shares. In return, Sasol was limited in its own commercial and retail sales to $9.23 \%$ market share in the retail market and to a limited volume in the commercial market.

Purchases by the 00 Cs accounted for about $90 \%$ of Sasol's white fuel output. Price regulation meant they were guaranteed a return on this product calculated on a rate of return on marketing assets. The MSA thus effectively provided for an allocation of markets between Sasol and the other oil companies - allocating Sasol to the inland upstream market and the 00Cs to the inland downstream market. Following indications from government that the fuels sector would be deregulated and pipeline capacity between the coastal and inland regions would be expanded, Sasol gave the stipulated five-year notice in 1998 to end the MSA in December 2003, freeing it to expand in the retail market, and opened merger discussions with Engen.

\subsection{Tribunal's decision}

The merger was blocked by the Tribunal, primarily due to vertical foreclosure concerns in the inland market for diesel and petrol. The Tribunal found that the logistics constraints in moving product from the coastal to the inland market meant that there was a separate inland market. In this market, the Tribunal found that the merger would create the potential for Sasol to foreclose the $00 C$ s by selling to its own marketing and retail network (acquired from Engen). Uhambo could credibly threaten to refuse to supply the $00 \mathrm{Cs}$, and had the incentive to do so. In addition, the Tribunal found that the 00Cs' ability to impose costs on Sasol by not supplying the volumes Sasol required for its coastal retail network was diminished by the merged entity including Engen's Durban-based refinery.

The inland supply, which was previously constrained by agreement through the MSA, was later constrained by logistical capacity - the inland marketers may import product from the coast, but because of inadequate logistical capacity they were only able to supply a portion of their needs (Tribunal decision, p. 66). The cancellation of the MSA meant that Sasol was no longer confined to supplying the $00 \mathrm{Cs}$ inland in proportion to their market share. The majority of Sasol's product could be absorbed by the Engen downstream operations. The Tribunal concluded that the merger would result in the dominant inland refiner merging with the considerable share of the inland and national downstream markets controlled by Engen.

The Tribunal thus assessed the merger as purely a vertical merger in the inland market of South Africa. The Tribunal identified the KwaZulu-Natal and inland refineries as being in different geographic markets for competition purposes and providing no horizontal competitive rivalry to each other because of the logistics constraints. Although the $00 \mathrm{Cs}$ were trucking some product from the coast required to service their inland clients, the Tribunal held that this did not mean that the 00 Cs could effectively service their inland requirement with their own product. 
The Tribunal concluded that Sasol aimed to protect its inland import parity pricing with this JV. The JV would absorb the bulk of Sasol's product through the Engen retail operations and this, along with the logistical capacity constraints, would mean Sasol would be able to apply pressure on its other customers to maintain inland IPP. Sasol's timing of the cancellation of the MSA was such that it would have been a number of years before the additional pipeline infrastructure was in place for coastal fuel to be a more viable alternative to inland purchasers. While the new pipeline would eventually allow the $00 \mathrm{Cs}$ to bring more product inland, the merger would enable Uhambo to place its product through its own marketing network (acquired from Engen). Sasol was not otherwise able to absorb its upstream output via organic growth of its marketing operations following the termination of the MSA. This organic growth was constrained by the 'Ratplan' (by which new petrol forecourts were approved). Sasol maintained that the new pipeline and deregulation would put it at the mercy of the other oil companies owing to the coastal companies being able to transport product to the inland region thus putting Sasol at risk of not being able to offload its product at the retail level.

\subsection{Assessment}

In line with the theoretical framework set out, key to understanding the impact of this merger on competition is understanding the bargaining game that occurs between Sasol and the 00Cs, how this would be affected by the merger and what this means for end consumers.

Sasol faces a relatively low cost of refining fuel, especially through its synfuels process in Secunda. The 00Cs can sell fuel at an inland retail price (regulated at the pump for petrol). The upstream and downstream firms can jointly realise a total profit equivalent to the difference between Sasol's cost and the retail inland BFP. The proportion of this profit captured by each depends on the availability and credibility of the outside options each firm has as alternatives to reaching an agreement on the wholesale price at which Sasol sells to the 00Cs.

Sasol's outside options are to sell its fuel into export markets and/or to reduce production at Natref (as it refines from imported crude and has much higher marginal cost). Sasol could also sell more product through its network (including Sasol-branded dealer-owned sites) by discounting the wholesale list price to compensate the dealer-owner for capital investment in the site (Tribunal decision, pp. 58-59). Finally, if Sasol did not get the inland IPP price it wanted from the $00 \mathrm{Cs}$ for diesel, it could push volumes directly into the commercial diesel market (Tribunal decision, pp. 59-60). We assess each in turn.

The price that Sasol can achieve in the first option is the export price (or an export parity price, $\varepsilon P P$ ) less the transport cost $(t)$ of moving product to the coast for export (see also the nonconfidential transcript of Mr Reid, Tribunal hearings, p. 2133).

$$
\text { Value of Sasol's outside option } 1=E P P-t
$$

The second option was for Sasol to cut back on its inland production from Natref, with a cost equal to the difference between the price of the refined product and marginal cost (relatively high given it is the refining of imported crude oil).

$$
\text { Value of Sasol's outside option } 2=P-M C
$$

Sasol therefore was not willing to accept a price that is lower than the best of the alternatives in (1) and (2). Other alternatives in the form of discounting to increase sales through the retail and commercial channels were also pursued. But Sasol was constrained by the Ratplan in expanding its retail footprint and by existing contractual arrangements in persuading dealer- 
owned sites to switch from 00 Cs to Sasol-branded sites. Sasol could also sell large volumes of diesel directly into the commercial diesel market through robust discounting to impact on the marketing margins of all oil companies on this product, and not just discounting to make incremental sales (see Oberholster, Tribunal hearings, p. 473).

The 00Cs' outside option was to transport product from the Durban refineries instead of purchasing from Sasol inland. The price the 00Cs would have to pay under this option is equal to the price at the coast, which is also an export parity price (as surplus not consumed at the coast would be sold into deep sea export markets) plus the transport cost of bringing the product from the coast inland.

$$
\text { Value of OOCs'outside option }=E P P+t
$$

This therefore represented the $00 C s^{\prime}$ maximum willingness to pay, contingent on those refineries being long on supply (hence not limited in quantity), and on the availability and cost of logistics to transport the product inland. The most cost-effective method of transport is by pipeline (the Durban Johannesburg Pipeline, DJP), while rail and road are other, more expensive, possibilities once the DJP was fully utilised. Around the time of the merger, the inland market was short, requiring some rail and road to be utilised in addition to the DJP, while the country as a whole was long, and there were exports from the coastal refiners. The outside option was thus at the road freight cost, as this was the only option that could readily accommodate additional volumes at short notice.

Significant focus was given in the hearings to the logistical constraints in transporting product inland by the 00Cs. Sasol also 'tied up' capacity in the Durban Witwatersrand Pipeline (DWP) by securing that pipeline for the transportation of gas instead of fuel. This reduced the 00C's bargaining power, as the threat of bringing product from the coast was more limited (Tribunal decision, p. 33). Other opportunities to absorb logistics capacity by Sasol were revealed in internal documents (Mr Oberholster, p. 426 Tribunal hearings).

The volumes over which the $00 \mathrm{Cs}$ could credibly threaten to bring in the bargaining game is thus between $E P P+t$ and $E P P-t$, or over twice the transport cost from inland to coast (using (1) and (3) above). Estimates for road transport were around 32-35c/litre (Tribunal decision, p. 37 ), and hence twice this would be in the order of $64-70$ c/litre (assuming the same cost in both directions as the transport is being done by different parties, not allowing for backhauling).

The game played out over 2003 as the termination of the MSA drew closer, as was evident in extensive cross-examination on Sasol's marketing strategy. The evidence is that Sasol did export fuel, both into overland and deep sea markets, and did cut back production at Natref (as put by Adv Cilliers to Mr Reid, pp. 2185-6, and Mr Oberholster, p. 360, Tribunal hearings). Sasol offered to contract for sales at discounts on $20 \%$ of its product, with the remainder at full inland BFP, and at the same time threatened to impose a 5 cents/litre surcharge above BFP for any spot sales made subsequently (Oberholster, p. 273, Tribunal hearings). These were not attractive enough amounts for all the $00 \mathrm{Cs}$ to accept (BP apparently did not, but others may have accepted).

Both sides thus apparently undertook relatively unattractive alternatives, which eroded the surplus available to them collectively - Sasol in cutting supply to the inland market by exporting and reducing production, and the $00 \mathrm{Cs}$ by transporting additional product inland from the coast by road. These actions point to the importance of information and the credibility of commitments that both sides sought to establish, in the context of repeated interactions. 
The attainable export price for Sasol is not known to the 00Cs (because of transport costs and the prices in different export markets). The 00 Cs also do not know the costs involved in cutting back production at Natref. On the other hand, the ability and associated costs of transporting product to the inland region from the coast by the 00Cs are not known to Sasol, especially given the need to bring additional road transport capacity into play to transport large additional volumes (see Oberholster's testimony around bargaining between Sasol and BP around logistical constraints in price determinations, p. 422). In addition, the availability of coastal volumes is also uncertain. Both sides took apparently costly decisions in order to convey information about their outside options and willingness to turn to them (which can be understood in terms of conveying preferences for risk or time).

The bargaining game in this case also involves a number of buyers in the inland downstream market, which makes it difficult for one downstream firm to know that its threat to exercise its outside option effectively imposes any cost on Sasol. It would be unsure whether Sasol would simply not sell to its rivals in the downstream market the volumes not sold to it. This weakens the individual firm's bargaining position and can be exploited by Sasol in negotiating individually with each customer, as appears to have happened.

The proportion of this incremental surplus that each gets depends on its relative bargaining power associated with the strength and credibility of its respective outside options, together with the perceived preferences of each player.

The key issue then was how the merger would have affected the outside options of each party and changes in relative bargaining power. This would have an effect on end customers to the extent that there was pass-through of discounts won by the 00Cs on their purchases from Sasol of diesel (not subject to price regulation). However, the Tribunal viewed discounting by Sasol in the diesel retail and commercial market as vigorous competition and did not explicitly see this in a broader integrated bargaining framework (Tribunal decision, p. 60).

The merger would have a significant impact on the outside options available to both sets of players. The supply and demand balance in the coastal market was an essential part of understanding the bargaining power of the $00 \mathrm{Cs}$. Without coastal capacity, the logistics constraints did not even come into play. The merger would mean that Sasol would acquire a very large part of the Durban refining capacity and could substantially reduce the costs of exporting by doing so from Enref. Sasol could also simply remove the surplus in the South African market as a whole - internal Sasol documents revealed the intention of shorting the local market by cutting volumes at Engen, moving the country to a net importing position (Tribunal decision, p. 52). The rivalry that was being reduced by the merger was thus of an alternative source of bulk supply, in a horizontal relationship to Sasol's own bulk supply when viewed within a bargaining framework.

The merger also substantially improved Sasol's options by providing it with the most extensive national retail and distribution network, through which it could push volumes if the 00 Cs did not accept inland BFP (Tribunal decision citation of Sasol internal document on the primary objective of the deal being to 'create leverage in wholesale fuel price to other oil companies by creating alternative distribution and value', p. 52).

By first engaging in market definition without working through the nature of competitive rivalry the Tribunal assessed the merger through a vertical lens only. Understanding the nature of competitive rivalry in a bargaining framework suggested an important horizontal dimension to the merger which, on this version of the relevant market, would incorporate the merging of 
Sasol's inland refining capacity with Engen's large coastal refinery.

\section{CHLOR-ALKALI HOLDINGS AND BOTSWANA ASH}

This transaction between two producers of chemical grade salt, Chlor-Alkali Holdings (CAH) and Botswana Ash (Botash), was approved by the Tribunal with certain conditions (Competition Tribunal case 34/LM/Apr09). CAH manufactured chemical grade salt at its Walvis Bay Salt Holdings (WBSH) operation in Namibia, while Botash produced salt as a by-product of its soda ash operation in Botswana. CAH also owned NCP Chlorchem (NCP), a user of salt in its chloralkali production and the only inland South African producer apart from Sasol in this downstream market.

In this transaction, the important role an independent WBSH played in enabling Sasol to bargain down Botash's prices was clearly revealed. This was acknowledged by the Tribunal, and the conditions imposed reflected the concern that, post-merger, WBSH would no longer pose this competitive constraint.

\subsection{Industry structure, product and the relevant geographic market}

Chemical grade salt, an intermediate industrial product, is an essential input into the chloralkali process, and chlor-alkali plants are the largest consumers of salt in South Africa. There are no substitutes for chemical-grade salt in this process, which is used to manufacture caustic soda, and chlorine and PVC further downstream. Pre-merger, both WBSH and Botash supplied Sasol's chlor-alkali plant at Sasolburg (see FIGURE 2). NCP sourced salt from sister company WBSH.

The geographic market was found to be limited to the inland region of South Africa, owing to the large transport costs in relation to the value of this product. Botash's locational advantage together with rail infrastructure meant that the transport costs associated with delivering salt to the inland South African market were distinctly lower than those associated with WBSH salt. WBSH had to ship product from Walvis Bay in Namibia to Richards Bay in KZN, and then truck it up to the inland area, as rail logistics between the coast and inland regions are poor. Owing to this locational advantage, Botash was able to secure a significant margin on its chemical grade salt sales to Sasol, and as such was assessed as exercising its market power.

However, Sasol maintained both Botash and WBSH as suppliers of salt to ensure security of supply, despite WBSH's salt being significantly more expensive than that of Botash. In terms of the traditional SSNIP (Small but Significant Non-transitory Increase in Price) test of 5\% to 10\% used to define markets, WBSH's product would not be included in the relevant market. Yet, WBSH provided some competitive constraint on Botash, because Sasol consistently sourced substantial amounts of product from it which was mixed with Botash's product before use.

\subsection{Tribunal finding}

The Commission initially recommended that the Competition Tribunal prohibit this merger based on the likelihood of a significant lessening of competition combined with the absence of mitigating factors. By considering Sasol's strategic incentives for sourcing from WBSH as an inferior alternative supplier, the Tribunal found that WBSH effectively constrained Botash pricing as its closest rival and therefore formed part of the "appropriate frame of reference" for 
analysis of the competitive effects of this merger. This was, however, not dependent on Sasol actually sourcing from WBSH but dependent on Sasol establishing that it could source from WBSH in order to exert competitive discipline on Botash.

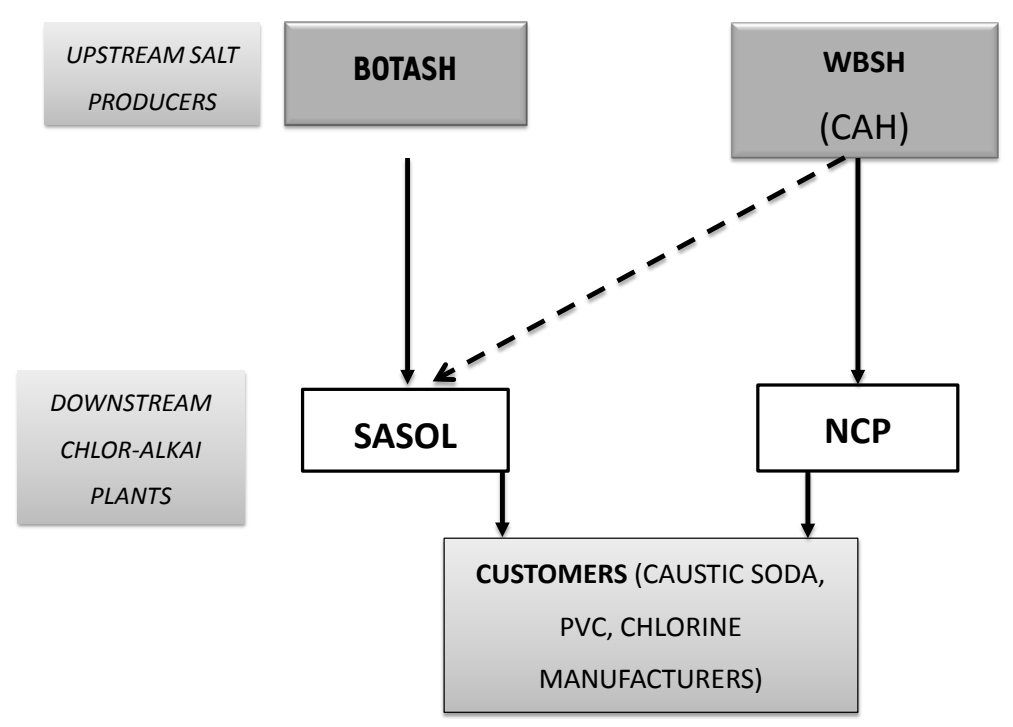

\section{FIGURE 2: Value chain in the inland region}

Source: Authors'own deduction

Sasol signed a long-term supply contract with Botash, before the Tribunal hearing, which guaranteed the supply of the chemical grade salt it required at 2009 prices with an annual maximum price adjustment factor built in. This agreement restricted the ability of the merged entity to raise prices to Sasol for at least 10 years. Therefore the harm that may have resulted from the increased market power of the merged entity and the resulting increase in prices was no longer a concern to the Commission. In addition, the merging parties agreed to extend these favourable supply terms to any other entrant in the inland market of South Africa which required chemical grade salt.

The Tribunal accepted the proposed conditions and cited the countervailing power argument as a 'key aspect' of the analysis - this position was used in order to evaluate whether the conditions were likely to protect Sasol and potential future entrants from the effects of this merger.

\subsection{Assessment}

In this merger, a traditional approach to defining geographic markets using a SNNIP test would have suggested that WBSH's product was not in the relevant market. Yet the significance of the availability of WBSH as an alternative, albeit an inferior one, had an impact on Sasol's ability to negotiate lower prices from Botash. 
The bargaining game between Botash and Sasol can once again be illustrated by the outside options available to each. The salt was a by-product of Botash's soda ash production and, as such, the costs of producing it were very low or close to zero. However, it could still sell this product to Sasol at a price that was close to the price of Sasol's next best alternative, WBSH.

Pre-merger, however, Botash was constrained in realising full monopoly profits by a number of factors.

- Firstly, Botash has large stockpiles of raw salt, and continuously produces these volumes as a by-product of its primary production of soda ash. These stockpiles, if not disposed of, could create an environmental hazard.

- Secondly, Botash did not, pre-merger, have alternative sources of demand to Sasol for its chemical-grade salt. The value of Botash's outside option was much lower than selling its product to Sasol.

Sasol's best outside option, although inferior in terms of higher prices compared to sourcing from Botash, was to source from WBSH. Another alternative was to source from Dampier, an Australian firm. This was not sustainable according to Sasol because, although the price difference between WBSH and Dampier's product was not large, substantial barriers, such as supply lags and payment terms, existed which were high enough to rule it out.

Botash's outside options were very poor, as it had low production costs given it being a byproduct of soda ash. Botash had large stockpiles of raw salt that could be converted into chemical-grade salt, but no readily available alternative customers apart from NCP. Transport costs and low deep sea export prices made the option of exporting very unattractive. There was thus a very large bargaining range between the outside options of Sasol and Botash.

Sasol exercised its outside option, regularly sourcing from WBSH. Apart from the possible security of having an alternative supplier, there appeared to be little reason for Sasol to source from WBSH aside from maintaining its bargaining position. Botash was cheaper and had the capacity to supply Sasol's entire demand, although the issue of sufficient rail capacity concerned Sasol.

While Botash was aware that Sasol sourced from WBSH, it did not know the prices Sasol paid for WBSH's salt. Imperfect information was thus very important in the outcome of the bargaining game, as Sasol's continued actual sourcing non-trivial volumes from the high cost WBSH conveyed misleading information about its apparent pricing. If Botash could have committed (through transparency and improved outside options) to pricing marginally below the WBSHdelivered price to Sasol, then Botash would have achieved the monopoly price.

In order for Botash to set prices marginally below WBSH's

(i) Botash had to be credibly able to commit to them, through reducing supply or supplying other markets; and

(ii) Botash had to know the approximate delivered price of WBSH salt to Sasol.

Viewed in this way, the impact of the merger on the competitive constraints on Botash is readily evident. The proposed merger removed the alternative and improved Botash's supply options for the inland South African region through the vertical integration with NCP. The information on transport costs and deep sea pricing from the operation of WBSH would also provide the merged entity with much greater transparency on Sasol's alternatives in the form of another import source. 
The Botash case clearly illustrates the importance of understanding outside options and exploiting imperfect information as part of competitive constraints in bargaining outcomes to extract lower prices from a monopoly upstream. It is also evident that, had Sasol not continued sourcing from WBSH, building up its reputation to turn to alternatives, then WBSH would not have been included in the defined market if the market were defined in the traditional sense. However, in the bargaining framework it is not the actual sourcing from WBSH but the credible threat to do so which is important.

\section{CONCLUSION}

In both the Sasol/Engen and CAH/Botash cases we find that an analysis of bargaining power played an important part in assessing the extent of market power and thus the effects of the merger. However, in the Sasol/Engen merger, by not properly taking into account bargaining power in the nature of rivalry in the market, the Tribunal defined a narrow geographic market and concluded that the effects of the merger were largely vertical. The competitive constraint that the 00Cs placed on Sasol owing to its credible threat to turn to an imperfect alternative in the inland region suggested that the upstream market definition should have been extended to include the KZN coastal region and, therefore, Engen's refining capacity in Durban. The consolidation of the upstream market would have been a strong argument in itself to block this merger on a horizontal consideration of the market.

By comparison, the Tribunal's acknowledgement of the competitive constraints that WBSH, as an inferior alternative, placed on Botash's pricing to Sasol led the Tribunal to primarily consider the horizontal aspects of the merger and therefore the merger being a move from duopoly to monopoly. WBSH constrained Botash in that Sasol had an outside option with which to threaten Botash. As a result, before the merger Sasol was able to actually source and credibly threaten to switch its custom from Botash to WBSH. Sasol was able to use these options (its countervailing power), as well as its knowledge of Botash's own lack of alternatives, to negotiate better prices from Botash. WBSH was included in the market even though, in a static analysis, it would not qualify to fall into the same market as Botash owing to the large price differential between the two. We note that the actual price differential resulted from the credibility of the threat of Sasol resorting to WBSH as part of its bargaining strategy and the costs which would be imposed on Botash.

These mergers demonstrate that rather than seeing countervailing power as a separate item on the list of factors to be considered, it is important to understand bargaining power as part of the nature of competitive rivalry when faced with concentration as both supplier and buyer levels. This includes defining the effective rivals in the market as sources of competitive discipline, and hence integrated with market definition. When prices and quantities are determined through bargaining one cannot use an approach to market definition that rests on an assumption that the market clears through supply decisions to serve a demand side approximated by many anonymous buyers.

By integrating the analysis of the nature of competitive rivalry with the market definition exercise, one can better assess the effect the merger is likely to have on competition. In bargaining outcomes key features are the identification of the outside options for both sides, the factors underlying these options, and information imperfections. The cases here highlight the importance of paying attention to information and the opportunities for strategic behaviour that information imperfections allow. 
Both of the mergers also illustrate that apparent monopolists can be disciplined by buyers, while monopolists themselves have avenues through which to respond to such bargaining power, with Sasol being a supplier in one, and a buyer in the other. Rey and Tirole (2006) indicate that a monopolist can re-establish its position and extract its monopoly profit under these conditions by engaging in exclusionary conduct, vertical integration and limiting its output to maintain high prices. In the context of merger analysis, it is important to properly map out the terrain in which competitive discipline over market power may already be taking place in order to capture the possible lessening of competition from the merger.

\section{LIST OF REFERENCES}

Baker, J. (2007). Market Definition: An Analytical overview. Antitrust Law Journal, 74, pp. 129-173.

Baker, J. \& Bresnahan, T.F. (2006). Economic Evidence in Antitrust: Defining Markets and Measuring Market Power, in Buccirossi, P. (ed.) Handbook of Antitrust Economics. Cambridge; MA: MIT Press.

Bishop, S. \& Walker, M. (2010). The Economics of EC Competition Law: Concepts, Applications and Measurement. London: Thomson Reuters.

Carlton, D. (2007). Market Definition: Use and Abuse. Competition Policy International, 3(1) [0nline] Available from: http://www.justice.gov/atr/public/eag/225693.pdf (Accessed 6 July 2011).

Carlton, D. \& Perloff, J.M. (2000). Modern Industrial Organization. New York: Pearson.

Chen, Z. (2007). Buyer Power: Economics Theory and Antitrust Policy, Research in Law and Economics, 22, pp. 12-40.

Church, J. \& Ware, R. (2000). Industrial Organization - A Strategic Approach. Boston: Irwin McGraw Hill.

Clarke, R., Davies, S., Dobson, P. \& Waterson, M. (2002). Buyer Power and competition in European food retailing. Cheltenham: Edward Elgar.

Coase, R. (1972). Durability and Monopoly, Journal of Law and Economics, 15, pp. 143-149.

Evans, D. \& Schmalensee, R. (2005). The industrial organization of markets with two-sided platforms. (NBER Working Paper 11603.)

Fudenberg, D. \& Tirole, J. (1984). The Fat Cat Effect, the Puppy Dog Ploy and the Lean and Hungry Look. American Economic Review, Papers and Proceedings, 74, pp. 361-368.

Geroski, P. (1998). Thinking creatively about markets. International Journal of Industrial Organization, 16, pp. 677-695.

Gual, J., Hellwig, M., Perrot, A., Polo, M., Rey, P., Schmidt, K. \& Stenbacka, R. (2005). An economic approach to Article 82, report by the Economic Advisory Group for Economic Policy. [On-line] Available: http://didattica.unibocconi.it/mypage/upload/48353_20081205_124239_EAGCP_ ART82REPORT.PDF. [Accessed 2 March 2011]

Hargreaves Heap, S. \& Varoufakis, Y. (2004). Game Theory - A critical text. London: Routledge. Hay, D. \& Vickers, J. (1987). The Economics of Market Dominance. Oxford: Blackwell.

Hawk, B. (2011). Annual proceedings of the Fordham Competition Law Institute. Huntington: Juris Publishing. 
U.S. Department of Justice and the Federal Trade Commission (2010). Horizontal Merger Guidelines. Issued 19 August 2010. [On-line] Available: http://www.ftc.gov/os/2010/08/100819hmg.pdf. (Accessed 6 July 2011).

ICN (International Competition Network) Merger Working Group: Investigation and Analysis Subgroup, (2006). ICN merger guidelines workbook. Fifth Annual ICN Conference in Cape Town April 2006. www.internationalcompetitionnetwork.com

Inderst, R. \& Shaffer, G. (2008). Buyer power in merger control, in Collins, W.D. (ed.) Issues in Competition Law and Policy, vol. II, pp. 1611-1635. Chicago: American Bar Association.

Inderst, R. \& Valletti, T. (2007). Market Analysis in the presence of Indirect Constraints and Captive Sales. Journal of Competition Law and Economics, 3(2), pp. 203-231.

Kaplow, L. (2010). Why (ever) define markets? Harvard Law Review, 124, pp. 437-517.

Motta, M. (2004). Competition policy: theory and practice. Cambridge: Cambridge University Press.

OECD (Organisation for Economic Development) (2000). Buying Power of Multiproduct retailers. OECD Journal of Competition Law and Policy, 2(1), pp. 81-194.

0’Donoghue, R. \& Padilla, A.J. (2006). The Law and Economics of Article 82 EC. Oxford: Hart Publishing.

Ordover, J.A. \& Saloner, G. (1989). Predation, Monopolization, and Antitrust, in Schmalensee, R. \& Willig, R. (eds.) Handbook of Industrial Organization. Amsterdam: North-Holland.

Osborne, M.J. \& Rubinstein, A. (1990). Bargaining and Markets. San Diego: Academic Press.

RBB Economics (2007). The competitive effects of buyer groups. Economic discussion paper series. Office of Fair Trading. [On-line] Available:

http://www.oft.gov.uk/OFTwork/publications/publication-categories/reports/Economicresearch/oft863. (Accessed 2 March 2011).

Rey, P. \& Tirole, J. (2006). A Primer on Foreclosure, in Armstrong, M. \& Porter, R. (eds.) Handbook of Industrial Organization III, Vol. 3. Amsterdam: North-Holland Publishing Company.

Röller, L. (2004). Buyer power in the $\varepsilon U$, in American Antitrust Institute, Buyer Power and Antitrust. Washington D.C., United States of America June 22, 2004. Washington D.C.: American Antitrust Institute.

Scheffman, D. \& Spiller, P. (1987). Geographic market definition under the US Department of Justice merger guidelines. Journal of Law and Economics, 30, pp. 123-147.

U.S. Department of Justice and the Federal Trade Commission (2010). Horizontal Merger Guidelines, Issued: August 19, 2010.

\section{South African Competition Tribunal decisions}

Competition Tribunal Case 06/LM/0ct99, Merger of Highveld Steel and Vanadium Corporation Ltd, Van Leer South Africa and Steelbank Merchants (Pty) Ltd t/a Drumpak.

Competition Tribunal Case 78/LM/Jul00, Merger of JD Group Limited and Ellerine Holdings Limited.

Competition Tribunal Case 101LMDec04, Merger of Sasol Ltd, Engen Ltd, Petronas Ltd and Sasol Oil (Pty) Ltd, Engen Ltd.

Competition Tribunal Case 80/CR/Sep06, Nationwide Airlines (Pty) Ltd and Comair v South African Airways (Pty). 
Competition Tribunal Case 34/LM/Apr09, Merger of Chlor-Alkali Holdings (Pty) Ltd and Botswana Ash (Pty) Ltd. 
Roberts, Corbett \& Das Nair 